\title{
PENGARUH MODEL PAKEM TERHADAP HASIL BELAJAR MATEMATIKA PESERTA DIDIK KELAS VII MTS NEGERI 2 KENDARI
}

\author{
Nela Arya Putri ${ }^{(1)}$, Kodirun ${ }^{2)}$, La Ndia $^{3)}$ \\ 1, 2) Jurusan Pendidikan Matematika FKIP Universitas Halu Oleo \\ Email : putrinela30@yahoo.co.id ${ }^{1)}$, kodirun@uho.ac.id ${ }^{2)}$, alndifiat@gmail.com ${ }^{3)}$
}

\begin{abstract}
Abstrak
Penelitian ini dilakukan dengan tujuan: (1) mengetahui hasil belajar matematika peserta didik dengan model PAKEM, (2) mengetahui hasil belajar matematika peserta didik yang diajar dengan model pembelajaran langsung, (3) mengetahui ada tidaknya pengaruh peserta didik yang diajar dengan menggunakan model PAKEM dengan model pembelajaran langsung pada peserta didik kelas VII MTs Negeri 2 Kendari. Populasi dalam penelitian ini adalah seluruh peserta didik kelas VII MTs Negeri 2 Kendari yang terdiri dari 7 kelas parallel dengan jumlah 181 peserta didik. Pengambilan sampel dilakukan dengan teknik purposive sampling. Teknik analisis data menggunakan statistic deskriptif dan statistic inferensial. Hasil penelitian secara deskriptif dan secara inferensial menunjukan bahwa: (1) Rata-rata hasil belajar peserta didik yang diajar dengan model PAKEM adalah67,7, (2) Rata-rata hasil belajar peserta didik yang diajar dengan model pembelajaran langsung adalah 60,06, dan (3) model PAKEM memiliki pengaruh terhadap hasil belajar matematika peserta didik pada materi persamaan dan pertidaksamaan linear satu variabel.
\end{abstract}

Kata Kunci : model PAKEM, hasil belajar matematika, peserta didik

\section{THE EFFECT OF THE PAKEM MODEL ON MATHEMATICS LEARNING OUTCOMES OF CLASS VII STUDENTS OF MTS NEGERI 2 KENDARI}

\begin{abstract}
This research was conducted with the aim of: (1) to find out the mathematics learning outcomes of taught using the PAKEM model, (2) to find out the mathematics learning outcomes of taught using models direct learning, (3) to determine whether there is an influence of students taught using the PAKEM model with a direct learning model for grade. The population in this study were all VII grade students of MTs Negeri 2 Kendari consisting of 7 parallel classes with a total of 181 students. Sampling was done by purposive sampling technique. Data analysis techniques using descriptive statistics and inferential statistics. The results of the study are descriptive and inferential shows that: (1) The average learning outcomes of students taught with the PAKEM model are 67.7, (2) The average learning outcomes of students taught with the direct learning model are 60.06 , and (3) the PAKEM model has an influence on the mathematics learning outcomes of grade VII MTs Negeri 2 Kendari students on the equation and linear inequalities of one variable.
\end{abstract}

Keywords: PAKEM model, learning outcomes mathematics, student 


\section{Pendahuluan}

Pendidikan telah memberikan pengaruh yang besar terhadap sumber daya manusia.Akibatnya, peningkatan pada mutu pendidikan berarti pula meningkatkan kualitas sumber daya manusia. Berbagai upaya telah dilakukan untuk meningkatkan mutu pendidikan yaitu salah satunya adalah dengan melakukan kajian-kajian dan pengembangan kurikulum pendidikan secara konsisten dan bertahap.

Pendidikan memiliki peran yang sangat penting dalam kehidupan bermasyarakat. Peran pendidikan adalah menjelaskan tentang tatanan masyarakat yang berlaku. Menerangkan pentingnya keharmonisan dalam menjaga eksistensi bersama pada tingkat individu, sosial dan kosmos dan mewariskan cara-cara bermasyarakat yang dapat melanggengkan keharmonisan dalam berinteraksi.

Sekolah merupakan salah satu tempat untuk melaksanakan proses pendidikan secara formal. Secara umum, proses pendidikan yang terjadi di dalam sekolah adalah proses belajar mengajar. Proses belajar dilakukan oleh peserta didik dan proses mengajar dilakukan oleh guru. Demi terwujudnya proses belajar mengajar yang efektif, sekolah harus memiliki sarana dan prasarana yang memadai. Mulai dari suasana lingkungan belajar peserta didik yang nyaman, alat penunjang pengajaran yang lengkap, serta model mengajar guru yang dapat membangkitkan semangat peserta didik untuk belajar.

Tujuan pendidikan pada dasarnya adalah untuk mengantarkan peserta didik menuju perubahan-perubahan tingkah laku. Perubahan tersebut baik berupa pengetahuan, sikap, moral, maupun sosial agar dapat hidup mandiri sebagai makhluk individu dan hidup bermasyarakat dengan baik sebagai makhluk sosial. Untuk mencapai tujuan tersebut peserta didik berinteraksi dengan lingkungan belajar, dimana pada lingkungan belajar di sekolah interaksi ini diatur oleh guru.

Sebagaimana dikemukakan oleh Rahmawati et al.(2014:234) bahwa keberhasilan pendidikan ditunjang oleh kemampuan guru dalam mengajar. Dalam proses pengajaran seorang guru harus mengembangkan strategi mengajar yang mengarah keaktifan optimal belajar murid. Disamping itu terdapat juga permasalahan yang muncul berkaitan dengan implementasi dalam penyelenggaraan pendidikan. Diantaranya disebabkan oleh padatnya materi yang menjadi tuntutan kurikulum yang berakibat hilangnya kreativitas guru dalam mengelolah pembelajaran, sehingga cenderung pada pembelajaran yang terpusat pada guru. Kondisi tersebut membawa akibat pada peserta didik yang pasif dan cenderung untuk menghafal konsep tanpa dibarengi dengan pemahaman memadai.

Guru adalah salah satu faktor utama yang menentukan mutu pendidikan. Sebab guru terlibat secara langsung dalam proses pendidikan yaitu berhadapan dengan peserta didik di dalam kelas. Seorang guru diharapkan dapat menciptakan lingkungan belajar yang dapat meningkatkan keterlibatan peserta didik secara langsung dan bertanggung jawab terhadap proses belajar mengajar itu sendiri. Selain faktor guru, peserta didik sebagai subjek dalam pembelajaran merupakan faktor yang harus mendapat perhatian yang cukup besar, hal ini dimaksudkan agar peserta didik lebih termotivasi untuk belajar.

Pitalis (2015: 48) mengemukakan bahwa pembelajaran yang berkualitas sangat tergantung dari motivasi pelajar dankreativitas pengajar. Pembelajar (peserta didik) yang memiliki motivasi tinggi ditunjangdengan pengajar (guru) yang mampu memfasilitasi motivasi tersebut akan membawapada keberhasilan pencapaian target belajar. Target belajar dapat diukur melaluiperubahan sikap dan kemampuan peserta didik melalui proses belajar. Desain pembelajaranyang baik, ditunjang fasilitas yang memadai, ditambah dengan kreativitas guru akanmembuat peserta didik lebih mudah mencapai target belajar.

PAKEM berasal dari konsep bahwa pembelajaran harus berpusat pada anak (student centered learning) dan pembelajaran harus bersifat menyenangkan (learning is fun), agar mereka termotivasi untuk terus belajar sendiri tanpa diperintah dan agar mereka tidak merasa terbebani atau takut. Untuk itu, maka aspek fun is learning menjadi salah satu aspek penting dalam pembelajaran PAKEM, di samping upaya untuk terus memotivasi anak agar anak mengadakan eksplorasi, kreasi, dan bereksperimen terus dalam pembelajaran (Rusman, 2014: 321).

Mengingat pentingnya pengetahuan akan matematika, maka pengajaran matematika perlu mendapat perhatian yang khusus.Pengajaran 
matematika menuntut peserta didik menunjukkan sikap yang aktif, kreatif, inovatif, dan bertanggung jawab.Materi matematika bersifat hierarki (berjenjang) dan sistematik, saling berhubungan antara satukonsep dengan konsep lain, maka dari awal hasil belajar matematika harus diperhatikan dengan baik. Sebab jika tidak, peserta didik akan mengalami kesulitan dalam memahami materi selanjutnya. Penggunaan model pembelajaran matematika tidak harus sama untuk tiap pokok bahasan, sebab dapat terjadi bahwa suatu model pembelajaran tertentu cocok untuk satu pokok bahasan tertentu tetapi tidak cocokuntuk pokok bahasan yang lain.

Hasil belajar merupakan salah satu ukuran mengenai tingkat keberhasilan dan bukti belajar peserta didik setelah menjalani proses pembelajaran. Bukti bahwa seseorang telah belajar ialah terjadinya perubahan tingkah laku pada orang tersebut, misalnya dari tidak tahu menjadi tahu, dan tidak mengerti menjadi mengerti.

Hasil belajar peserta didik merupakan hasil akhir dari suatu proses belajar mengajar yang terjadi di dalam kelas. Sehingga proses belajar mengajar yang berkualitas sangat mempengaruhi hasil belajar tersebut. Adapun model pembelajaran yang biasa diterapkan oleh guru di kelas adalah model pembelajaran langsung.Model ini cenderung meminimalkan keterlibatan peserta didik, sehingga guru lebih dominan dalam pembelajaran.Dalam aktivitas pembelajaran, guru hanya menyampaikan materi secara langsung dan peserta didik bertanya ketika mengalami kesulitan dalam memahami materi tersebut.

Tidak berbeda jauh dengan yang terjadi pada MTs Negeri 2 Kendari. Menurut penuturan guru matematikanya, proses pembelajaran masih sering menggunakan proses pembelajaran langsung, yakni peran guru lebih dominan atau pusat pembelajaran terletak pada guru dan peserta didik lebih banyak yang pasif.Peserta didik lebih cenderung menghafal dari pada memahami materi dan masih ada juga peserta didik yang menganggap materi matematika sulit sehingga motivasi belajarnya kurang.Peserta didik juga kurang diupayakan untuk berusaha memahami sendiri konsep-konsep matematika, akibatnya mereka sangat tergantung terhadap apa yang telah disampaikan guru. Misalnya, ketika peserta didik diberikan contoh soal lain yang berbeda dengan contoh soal yang diajarkan oleh guru, maka sebagian besar peserta didikakan mengalami kesulitan dalam memecahkannya. Hal ini diduga menjadi salah satu penyebab rendahnya aktivitas peserta didik dalam pembelajaran matematika yang mengakibatkan peserta didik kesulitan dalam belajar sehingga hasil belajar mereka tidak maksimal.

Berdasarkan hasil observasi awal terhadap hasil belajar matematika kelas VII MTs Negeri 2 Kendari diperoleh informasi bahwa rata-rata hasil belajar peserta didik kelas VII belum mencapai KKM yang telah ditetapkan.KKM yang ditetapkan oleh sekolah yaitu 75 .

Fakta menunjukkan bahwa selama ini proses pembelajaran yang diterapkan belum sesuai. Diperlukan suatu tindakan nyata untuk meningkatkan kualitas pembelajaran.Salah satunya adalah dengan menggunakan model pembelajaran yang dapat meningkatkan daya kreativitas peserta didik. Terdapat banyak model pembelajaran matematika yang memberikan kesempatan kepada peserta didik untuk aktif belajar mandiri dan mengembangkan kreativitas dalam pembelajaran matematika. Salah satunya adalah model PAKEM (Partisipatif, Aktif, Kreatif, Efektif, dan Menyenangkan). Model PAKEM berasal dari konsep bahwa pembelajaran harus berpusat pada anak (studentcentered learning) dan pembelajaran harus bersifat menyenangkan (learning is fun), agar mereka termotivasi untuk terus belajar sendiri tanpa diperintah dan agar mereka tidak merasa terbebani atau takut. Untuk itu, maka aspeklearningis fun menjadi salah satu aspek penting dalam pembelajaran model PAKEM, di samping upaya untuk terus memotivasi anak agar anak mengadakan eksplorasi, kreasi, dan bereksperimen terus dalam pembelajaran (Rusman, 2014).

Eka Lestari (2015: 70) mengemukakan bahwa model PAKEM yaitu salah satu model pembelajaran yang melibatkan peserta didik secara optimal, melibatkan aktivitas peserta didik dalam mengakses berbagai informasi, memotivasi peserta didik untuk lebih kreatif dalam pembelajaran sehingga muncul pemahaman baru pada peserta didik, dengan sendirinya terbentuk kompetensi peserta didik seutuhnya melalui proses pembelajaran yang menyenangkan.Model PAKEM sangat cocok diterapkan pada pembelajaran matematika 
karena dalam pembelajaran matematika, tidak cukup ingin mengetahui dan menghafal konsepkonsep matematika tetapi juga dibutuhkan suatu pemahaman serta kemampuan menyelesaikan persoalan matematika dengan baik dan benar. Melalui model pembelajaran ini, peserta didik dapat mengemukakan pemikirannya, saling bertukar pendapat, saling bekerja sama jika ada temannya yang mendapatkan kesulitan. Hal ini dapat meningkatkan motivasi peserta didik untuk mengkaji dan menguasai mata pelajaran matematika sehingga nantinya akan meningkatkan hasil belajar matematika peserta didik.

Rosdiana dan Anwar (2014: 158) menyatakan pemilihan model pembelajaran yang tepat dalam pembelajaran matematika akan mengaktifkan peserta didik serta menyadarkan peserta didik bahwa matematika tidak selalu membosankan. Model pembelajaran PAKEM, yaitu suatu model pembelajaran yang melibatkan peserta didik secara optimal, melibatkan aktivitas peserta didik dalam mengakses berbagai informasi, memotivasi peserta didik untuk lebih kreatif dalam pembelajaran sehingga muncul pemahaman baru pada peserta didik, dengan sendirinya terbentuk kompetensi peserta didik seutuhnya melalui proses pembelajaran yang menyenangkan (Zarkasyi, 2015: 70).

Dalam model PAKEM menurut (Rusman, 2010: 323); guru dituntut untuk dapat melakukan kegiatan pembelajaran yang dapat melibatkan peserta didik melalui partisipatif, aktif, kreatif, efektif dan menyenangkan yang pada akhirnya membuat peserta didik dapat menciptakan membuat karya, gagasan,

pendapat, ide atas hasil penemuannya dan usahanya sendiri, bukan dari gurunya.

\section{Metode}

Jenis penelitian yang digunakan dalam penelitian ini adalah penelitian eksperimen semu, karena penelitian ini mencari pengaruh perlakuan berupa model PAKEM terhadap hasil belajar matematika peserta didik. Terdapat dua kelompok/kelas sampel dalam rancangan ini, yaitu kelas eksperimen dan kelas kontrol. Penentuan kelas sampel dilakukan dengan menggunakan teknik purposive sampling. Jenis penelitian eksperimen yang digunakan adalah post-test only control design.

Populasi dalam penelitian ini adalah seluruh peserta didik kelas VII MTs Negeri 2 Kendari tahun ajaran 2019/2020yang berjumlah 181 peserta didik terdistribusi dalam 7 kelas yang tersebar secara heterogen. Populasi peserta didik kelas VII MTs Negeri 2 Kendari tahun ajaran 2019/2020.

Penentuan sampel dalam penelitian ini dilakukan dengan menggunakan teknik purposive sampling yaitu dengan pemilihan dua kelas yang memiliki kemampuan matematika yang relatif sama. Sehingga dipilih dua kelas secara acak untuk menentukan kelas eksperimen dan kelas kontrol, $\mathrm{VII}_{4}$ sebagai kelas kontrol dan kelas $\mathrm{VII}_{5}$ sebagai kelas eksperimen.

Variabel bebas dalam penelitian ini adalah perlakuan berupa pembelajaran matematika dengan menggunakan model PAKEM (X). Variabel terikat dalam penelitian ini adalah hasil belajar matematikapeserta $\operatorname{didik}(\mathrm{Y})$.

Adapun desain yang digunakan digambarkan pada Tabel 1 .

\section{Tabel 1}

Desain Penelitian

\begin{tabular}{ccc}
\hline Kelompok & Perlakuan & Posttest \\
\hline (R)Eksperimen & $\mathrm{X}_{1}$ & $\mathrm{O}_{1}$ \\
\hline (R)Kontrol & $\mathrm{X}_{2}$ & $\mathrm{O}_{2}$ \\
\hline
\end{tabular}

(Sugiyono, 2011: 112)

Keterangan :

$\mathrm{X}_{1}=$ Pembelajaran matematika dengan model PAKEM

$\mathrm{X}_{2}=$ pembelajaran matematika dengan model pembelajaran langsung
$\mathrm{O}_{1}=$ Pemberian tes akhir (post-test) pada kelaseksperimen

$\mathrm{O}_{2}=$ Pemberian tes akhir (post-test) pada kelaskontrol

Desain penelitian di atas terdapat dua kelompok yang masing masing dipilih secara 
purposive sampling. Selanjutnya kelas eksperimen diajar dengan model PAKEM dan kelas kontrol diajar dengan model pembelajaran langsung. Pada pertemuan terakhir, masingmasing kelas diberikan tes akhir untuk mengetahui hasil belajar matematikapeserta didik.

Penelitian ini mempunyai instrumen yaitu lembar observasi. Lembar observasi digunakan untuk mengukur aktivitas guru dan peserta didik dalam proses pembelajaran matematika dengan menggunakan model PAKEM

Lembar observasi peserta didik digunakan untuk melihat kegiatan, sikap dan respon peserta didik selama proses pembelajaran saat penerapan model PAKEM. Hal-hal yang diperhatikan dalam menentukan aspek apa saja yang diobservasi yaitu aspek yang diamati harus tampak atau muncul dalam aktivitas tertentu, aspek yang diamati hendaknya terukur, aspek yang diamati mengacu pada indikator pencapaian kompetensi, dan aspek yang diamati dituangkan dalam pernyataan atau butir indikator yang menggunakan kata kerja operasional yang memiliki arti jelas. Pengamatan dilakukan dengan melihat pedoman pada lembar observasi yang telah disusun Peneliti menetapkan 20 indikator untuk mengukur aktivitas peserta didik. Pengamat memberikan tanda pada kolom skor $(1,2,3,4$, dan 5) sesuai dengan aktivitas peserta didik dalam pembelajaran. Adapun ketentuan pemberian skor adalah sebagai berikut:

Skor 1 jika banyak peserta didik yang melakukan aktivitas $0 \%<\mathrm{x} \leq 20 \%$

Skor 2 jika banyak peserta didik yang melakukan aktivitas $20 \%<\mathrm{x} \leq 40 \%$

Skor 3 jika banyak peserta didik yang melakukan aktivitas $40 \%<\mathrm{x} \leq 60 \%$

Skor 4 jika banyak peserta didik yang melakukan aktivitas $60 \%<\mathrm{x} \leq 80 \%$

Skor 5 jika banyak peserta didik yang melakukan aktivitas $80 \%<\mathrm{x} \leq 100 \%$

Penelitian ini untuk mengukur adanya pengaruh model PAKEM terhadap hasil belajar matematika peserta didik, digunakan instrumen penelitian berupa tes tertulis dalam bentuk uraian untuk tes akhir pada materi persamaan dan pertidaksamaan linear satu variabel yang disusun oleh peneliti. Sebelum digunakan, instrumen tersebut dianalisis terlebih dahulu melalui panelis untuk mengetahui validitas dan reliabilitasnya.Jumlah panelis yang ada dalam penelitian ini terdiri dari 2 orang dosen yang semuanya merupakan dosen pendidikan matematika Universitas Halu Oleo dan 1 orang guru dari MTs Negeri 2 Kendari.

Format isian penilaian panelis dari instrumen hasil belajar matematika peserta didik adalah mencocokkan setiap butir soal dengan kompetensi dasar dan standar kompetensi dengan skor penilaian 1 sampai 5 dengan ketentuan, skor 1 jika dalam pernyataan tidak satupun kriteria yang muncul, skor 2 jika dalam pernyataan hanya ada satu kriteria yang muncul, skor 3 jika dalam pernyataan hanya ada dua kriteria yang muncul, skor 4 jika dalam pernyataan ada tiga kriteria yang muncul dan skor 5 jika dalam pernyataan ada semua kriteria muncul.

Uji validitas dan reliabilitas instrumen penelitian yang dilakukan pada penelitian ini adalah uji panelis. Analisis validitas penilaian panelis digunakan untuk mengetahui validitas konsep instrumen. Adapun kriteria valid atau tidaknya instrumen didasarkan pada nilai Vi. Validitas tes hasil belajar dihitung menggunakan rumus Aiken, yaitu:

$$
V_{i}=\frac{\sum n_{i}\left|i-i_{0}\right|}{N(c-1)}
$$

(Aiken, 1985)

Keterangan :

$V_{i}=$ validitas isi

$n_{i}=$ jumlah panelis yang memilih $\mathrm{i}$

$\mathrm{i}=$ skor pilihan setiap butir instrumen

$i_{0}=$ skor paling rendah yaitu 1

$\mathrm{N}=\operatorname{sigma} n_{i}$

$\mathrm{C}=$ skor pilihan yang tertinggi yaitu 5

Reliabilitas menunjuk pada pengertian bahwa suatu instrumen cukup dapat dipercaya untuk digunakan sebagai alat pengumpul data. Suatu tes dikatakan reliabel jika hasil pengukuran yang dilakukan dengan menggunakan tes tersebut terhadap suatu subjek, senantiasa menunjukkan hasil yang sesuai dengan kriteria reliabilitas. Reliabilitas tes ditentukan dengan menggunakan rumus Alpha Cronbach yaitu:

$$
\mathrm{r}=\left[\frac{\mathrm{n}}{\mathrm{n}-1}\right]\left[1-\frac{\sum \mathrm{S}_{\mathrm{i}}^{2}}{\mathrm{~S}_{\mathrm{t}}^{2}}\right]
$$

(Lestari dan Yudhanegara, 2015: 206)

Keterangan:

$\mathrm{r}=$ koefisien reliabilitas

$\mathrm{n}=$ banyak butir tes 
$\mathrm{S}_{\mathrm{i}}^{2}=$ variansi skor butir soal ke-i

$\mathrm{S}_{\mathrm{t}}^{2}=$ variansi skor total

Hasil uji validitas konstruk (construct validity) instrumen tes hasil belajar matematika peserta didik berdasarkan penilaian panelis. Berdasarkan penilaian 3 orang panelis untuk soal posttest dari soal nomor 1, 2, 3, 4, 5, 6 dan $7>0,6$ sehingga dapat dikatakan bahwa seluruh soal valid.

Teknik pengumpulan data dalam penelitian ini menggunakan metode observasi dan metode tes. Metode observasi menggunakan lembar observasi, diperoleh data aktivitas guru dan aktivitas peserta didik. Observasi dilakukan disetiap pertemuan. Untuk tes hasil belajar matematika, dilakukan pada akhir pembelajaran pada pertemuan terakhir pada kelas eksperimen dan kelas kontrol. Kemudian tes tersebut dikerjakan oleh peserta didik, masing-masing soal yang telah dikerjakan diberikan skor berdasarkan sistematika proses pengerjaannya. Selanjutnya, hasil pekerjaan peserta didik dikumpulkan oleh peneliti untuk diperiksa dan dikoreksi serta diberi nilai. Nilai dari hasil pekerjaan peserta didik tersebut kemudian dijadikan data dalam penelitian ini.

Teknik analisis data dalam penelitian ini menggunakan dua teknik analisis, yaitu analisis deskriptif dan analisis inferensial.

Analisis deskriptif dimaksudkan untuk mendeskripsikan hasil belajar matematika peserta didik melalui nilai rata-rata yang diperoleh peserta didik. Analisis deskriptif hanya melihat gambaran sampel dalam bentuk rata-rata $(\overline{)}$, median ( ), modus ( ), standar deviasi ( ), varians ( ), nilai minimum ( ), nilai maksimum ( ), skewness (kemiringan), dan kurtosis yang diperoleh dengan bantuan Data Analysis pada Microsoft Excel.

Sedangkan proses analisis data aktivitas belajar peserta didik pada waktu pembelajaran dalam penelitian ini dilakukan dengan menghitung persentase aktivitas peserta didik selama proses pembelajaran. Persentase tersebut diperoleh dengan menghitung jumlah skor yang diperoleh pengamat dari setiap pertemuan yang dilaksanakan.

\section{Hasil}

\section{Analisis Deskriptif}

Hasil observasi pelaksanaan pembelajaran dengan model PAKEM
Keterlaksanaan kegiatan pembelajaran di kelas diamati oleh pengamat. Proses analisis data aktivitas belajar peserta didik dan aktivitas guru dilakukan dengan menggunakan model PAKEM. Deskripsi tentang ditunjukan melalui persentase aktivitas peserta didik dan aktivitas guru selama proses pembelajaran. Data tersebut diperoleh melalui keterlaksanaan aktivitas guru dan aktivitas peserta didik. Berdasarkan hasil observasi di atas diperoleh bahwa tingkat kemampuan guru dalam melaksanakan pembelajaran dengan model PAKEM menunjukkan hasil yang baik. Hal ini dapat dilihat dari adanya peningkatan persentase dari tiap-tiap pertemuan. Pelaksanaan pembelajaran pada pertemuan pertama mencapai $79 \%$, pertemuan kedua mencapai $92 \%$ dan pertemuan ketiga, keempat, kelima, dan keenam mencapai $100 \%$.

Hasil rekapitulasi aktivitas peserta didik dalam pelaksanaan pembelajaran matematika menggunakan model PAKEM pada materi persamaan dan pertidaksamaan linear satu variabel yang dilaksanakan selama 6 pertemuan mengalami peningkatan persentase dari tiaptiap pertemuan. Aktivitas peserta didik pada pertemuan pertama mencapai $70 \%$, pertemuan kedua mencapai $79 \%$, pertemuan ketiga mencapai $85 \%$, pertemuan keempat mencapai $89 \%$, pertemuan kelima mencapai $92 \%$, dan pertemuan keenam mencapai $93 \%$.

\section{Hasil beajar matematika peserta didik kelas VII MTs Negeri 2 Kendari}

Data yang diperoleh dari nilai post test hasil belajar matematika peserta didik, yang pembelajarannya menggunakan model PAKEM. Soal yang sebelumnya berjumlah 7 soal dilakukan uji panelis lalu dianalisis validitas dan reabilitasnya. Selanjutnya soal yang telah valid dan reliabel tersebut digunakan untuk posttest pada kelas VII4 dan VII5. Setelah dilakukan tes maka diperoleh hasil deskriptif statistik yang berupa rata-rata (), median ( ), modus ( ), standar deviasi ( ), varians ( ), nilai minimum ( ), nilai maksimum ( ), skewness (kemiringan), dan kurtosis.

Distribusi nilai post test merupakan distribusi nilai yang diperoleh peserta didik yang diberi perlakuan berupa model PAKEM. Adapun distribusi data post test hasil belajar matematika peserta didik yang diajar dengan 
model PAKEM dapat dilihat pada tabel 2 berikut.

Tabel 2

Distribusi Post Test Peserta Didik

\begin{tabular}{ccc}
\hline Kelas & Frekuensi & Persentase \\
\hline $31-40$ & 0 & $0 \%$ \\
\hline $41-50$ & 3 & $9,09 \%$ \\
\hline $51-60$ & 4 & $12,12 \%$ \\
\hline $61-70$ & 9 & $27,27 \%$ \\
\hline $71-80$ & 12 & $36,36 \%$ \\
\hline $81-90$ & 5 & $15,15 \%$ \\
\hline Jumlah & 33 & $100 \%$ \\
\hline
\end{tabular}

Data hasil belajar matematika peserta didik yang diajar dengan menggunakan model pembelajaran langsung diperoleh dari tes hasil belajar matematika pada materi persamaan dan pertidaksamaan linear satu variabelyang dilaksanakan pada kelas $\mathrm{VII}_{4}$.
Distribusi nilai post test merupakan distribusi nilai yang diperoleh siswa yang diberi perlakuan berupa model PAKEM. Adapun distribusi data post test hasil belajar matematika peserta didik yang diajar dengan model pembelajaran langsung dapat dilihat pada tabel 3 berikut.

Tabel 3

Distribusi Hasil Post Test Peserta Didik Model Pembelajaran Langsung

\begin{tabular}{ccc}
\hline Kelas & Frekuensi & Persentase \\
\hline $31-40$ & 2 & $6,06 \%$ \\
\hline $41-50$ & 4 & $12,12 \%$ \\
\hline $51-60$ & 14 & $42,42 \%$ \\
\hline $61-70$ & 4 & $12,12 \%$ \\
\hline $71-80$ & 9 & $27,27 \%$ \\
\hline $81-90$ & 0 & $0 \%$ \\
\hline Jumlah & 33 & $100 \%$ \\
\hline
\end{tabular}

Model pembelajaran langsung merupakan salah satu dari macam-macam model pembelajaran. Berdasarkan pengertian pembelajaran langsung yang dikemukakan (Sofan Ami \& Iif Khoiru Ahmadi, 2010: 39) bahwa model pembelajaran langsung (Direct Instruction) merupakan salah satu model pembelajaran yang dirancang khusus untuk mengembangkan belajar peserta didik tentang pengetahuan procedural dan pengetahuan deklaratif yang terstruktur

Data hasil belajar matematika peserta didik yang diajar dengan menggunakan model pembelajaran langsung diperoleh dari tes hasil belajar matematika pada materi persamaan dan pertidaksamaan linear satu variabel yang dilaksanakan pada kelas VII4. Setelah dilakukan tes maka diperoleh hasil deskriptif statistik yang berupa rata-rata, median, modus, standar deviasi, varians, nilai minimum, skewness (kemiringan), dan kurtosis, nilai maksimum.

Distribusi nilai post test merupakan distribusi nilai yang diperoleh siswa yang diberi perlakuan berupa model PAKEM. Adapun distribusi data post test hasil belajar matematika peserta didik yang diajar dengan model pembelajaran langsung adalah sebagai berikut:

Data hasil belajar matematika peserta didik kedua kelas tersebut kemudian dianalisis dengan bantuan Data Analysis pada Microsoft Excel. 
Tabel 4

Hasil Analisis Deskriptif Kelas Eksperimen dan Kelas Kontrol

\begin{tabular}{ccc}
\hline Deskriptif Statistik & $\begin{array}{c}\text { Kelas } \\
\text { Eksperimen }\end{array}$ & Kelas Kontrol \\
\hline N(banyak data) & 33 & 33 \\
\hline Mean (rata-rata) & 67.70 & 60.06 \\
\hline Median & 71 & 58 \\
\hline Modus & 81 & 58 \\
\hline Standar deviasi & 11.620254 & 12.04403222 \\
\hline Varians & 135.0303 & 145.0587121 \\
\hline Nilai minimum & 42 & 35 \\
\hline Nilai maksimun & 82 & 79 \\
\hline Skewness & -0.704249803 & 0.226357454 \\
\hline Kurtosis & -0.258506459 & 0.559307029 \\
\hline
\end{tabular}

tidak. Hal ini diperlukan untuk menentukan

Berdasarkan output data di atas, diketahui bahwa jumlah peserta didik pada kelas eksperimen dan kelas kontrol masing-masing 33 peserta didik. Pada kelas eksperimen diketahui nilai rata-ratanya $=67.70$ dengan median $=71$ dan modus $=81$. Nilai peserta didik terendah (minimum) yaitu 42 , dan nilai peserta didik tertinggi (maksimum) yaitu 82, dengan standard deviasi sebesar 11.62. Data hasil belajar yang digunakan menceng kiri atau negatif (nilai skewness $=-0.70<0$ ) yang artinya data tersebut memiliki lebih banyak nilai observasi berada diatas nilai rata-rata. Sedangkan data hasil belajar yang digunakan platikurtik (nilai kurtosis $=-0.26<3$ ).

Pada kelas kontrol diketahui nilai rataratanya $=60.06$ dengan median $=58$ dan modus $=58$. Nilai peserta didik terendah (minimum) yaitu 35, dan nilai peserta didik tertinggi (maksimum) yaitu 79, dengan standard deviasi sebesar 12.04. Data hasil belajar yang digunakan menceng kiri atau negatif (nilai skewness = $0.23<0$ ) yang artinya data tersebut memiliki lebih banyak nilai observasi berada diatas nilai rata-rata. Sedangkan data hasil belajar yang digunakan platikurtik (nilai kurtosis $=-0.56<$ $3)$.

\section{Analisis Inferensial}

\section{Uji Normalitas}

Uji normalitas dilakukan untuk mengetahui bahwa data yang diperoleh berasal dari populasi yang berdistribusi normal atau jenis analisis data yang digunakan.

Hipotesis statistik yang digunakan :

HO : Sampel berasal dari populasi yang berdistribusi normal

H1 : Sampel berasal dari populasi yang tidak berdistribusi normal

Pengujian normalitas dilakukan dengan menggunakan uji Chi kuadrat ( ). Hasil pengujian normalitasdata hasil posttest peserta didikpada kelas VII5yang diajar dengan model PAKEM, berdasarkan hasil perhitungan diperoleh nilai hitung $=2,9601$. Selanjutnya dilakukan perhitungan nilai tabel dengan taraf signifikan 0,05 pada $\mathrm{dk}=\mathrm{k}-1$, dan $\mathrm{k}=$ banyak kelas interval data. sehingga dipeoleh tabel $=$ 0,$05 ; 9-1=0,05 ; 8=15,5073$. Jadi, hitung < tabel yakni2,9601<15,5073 sehingga $\mathrm{H} 0$ diterima. Berarti data hasil belajar matematika peserta didikpada kelas VII5 dinyatakan berdistribusi normal.

Selanjutnya, hasil pengujian normalitas data hasil posttest peserta didikpada kelas VII4 (kontrol) yang diajar dengan model pembelajaran langsung. Berdasarkan hasil perhitungan di atas diperoleh nilai hitung = 10,3992. Selanjutnya dilakukan perhitungan nilai tabel dengan taraf signifikan 0,05 pada $\mathrm{dk}$ $=\mathrm{k}-1$, dan $\mathrm{k}=$ banyak kelas interval data. Sehingga dipeoleh tabel $=0,05 ; 9-1=0,05 ; 8=$ 15,5073. Jadi, hitung< tabel yakni 10,3992 $<15,5073$ sehingga H0 diterima. Berarti data hasil belajar matematika peserta didikpada kelas VII4 dinyatakan berdistribusi normal. 
Tabel 5

Hasil analisis uji normalitas

\begin{tabular}{ccc}
\hline \multirow{2}{*}{ Statistik } & \multicolumn{2}{c}{ Nilai Statistik } \\
\cline { 2 - 3 } & Eksperimen & Kontrol \\
\hline N & 33 & 33 \\
\hline Asymp. Sig. (2-tailed) & 0,361 & 0,503 \\
\hline
\end{tabular}

Pengujian homogenitas varians dua

Dapat dilihat nilai Asymp. Sig. (2-tailed) untuk kelas eksperimen adalah $0,361>\alpha$ (dengan $\alpha$ 0,05), sehingga $\mathrm{H} 0$ dapat diterima. Hal ini dapat disimpulkan bahwa data hasil eksperimen berdistribusi normal. Sedangkan untuk kelas kontrol terlihat bahwa Asymp. Sig. (2-tailed) untuk kelas kontrol adalah 0,503 $>\alpha$ (dengan $\alpha 0,05$ ), sehingga $\mathrm{H} 0$ dapat diterima. Hal ini dapat disimpulkan bahwa data hasil belajar matematika peserta didik pada kelas kontrol berdistribusi normal.

Karena kedua data tersebut tersebut berasal dari populasi yang terdistribusi normal maka pengujian dilakukan dengan uji statistik parametrik.

\section{Uji homogenitas}

Uji homogenitas data ini bertujuan untuk mengetahui apakah data hasil belajar matematika kedua kelompok yang diteliti memiliki varians yang sama (homogen) atau tidak.

Hipotesis statistik yang digunakan :

H0 : Data kedua kelompok memiliki varians yang homogen

H1 : Data kedua kelompok memiliki varians yang tidak homogen belajar matematika peserta didik pada kelas

sampel yang berdistribusi normal dengan jumlah sampel sebanyak 33 peserta didik kelas VII5sebagai kelas eksperimen dan 33 peserta didik kelas VII4 sebagai kelas control dan dilakukan dengan rumus :

$$
F=\frac{\text { Varians terbesar }}{\text { Varians terkecil }}
$$

Berdasarkan deskripsi data yang diperoleh dari hasil belajar matematika peserta didik kelas VII5 dan VII4, yakni varians data kelas VII5 sebesar 135,0303 dan varians data kelasVII4 sebesar 145,0587 maka diperoleh :

$$
F=\frac{145,0587}{135,0303}=1,0743
$$

Nilai di atas diambil sebagai nilai Fhitung. Selanjutnya ditentukan nilai kritis ditribusi $\mathrm{F}$ yaitu dk pembilang $=\mathrm{n}-1 \mathrm{dan} \mathrm{dk}$ penyebut $=\mathrm{n}$ - 1. Dimana $\mathrm{n}$ pada dk pembilang berasal dari jumlah sampel varians terbesar, sedangkan $n$ pada dk penyebut berasal dari jumlah sampel varians terkecil. Jumlah sampel untuk kelas VII5 adalah 33 dan jumlah untuk kelas VII4 adalah 33 , maka dk pembilang $33=33-1$ yaitu $32, \mathrm{dk}$ penyebut $=33-1=32$. Dengan $\alpha=0,05, \mathrm{dk}$ pembilang $=32$, dan dk penyebut $=32$ diperoleh nilai Ftabel $=1,808$. Karena nilai Fhitung $<$ Ftabel atau $1,0743<1,808$, maka H0 diterima, sehingga varians kedua data tersebut homogen.

Tabel 6

Hasil uji homogenitas

\begin{tabular}{cc}
\hline Statistik & Nilai Statistik \\
\hline Sig. & 0,812 \\
\hline & Uji hipotesis
\end{tabular}

Berdasarkan uji homogogenitas menggunakan aplikasi SPSS, diperoleh nilai Sig. $0,812>\alpha$ (dengan $\alpha 0,05)$ maka H0 diterima.

Berdasarkan hasil analisis baik menggunakan rumus uji-F secara manual maupun menggunakan aplikasi SPSS, menunjukkan bahwa H0 diterima. Sehingga dapat disimpulkan bahwa data kedua kelompok memiliki varians yang sama (homogen).
Data yang diperoleh berdistribusi normal dan kedua kelompok memiliki varians yang homogen, maka untuk menguji ada perbedaan nyata antara model PAKEM terhadap hasil belajar matematika peserta didik kelas VII MTs Negeri 2 Kendari, digunakan uji-t sampel independen (Independen Sampel t Test). 
Secara statistik hipotesis tersebut dinyatakan:

$$
\mathrm{H}_{0}: \mu_{1}=\mu_{2} \quad \text { lawan } \quad \mathrm{H}_{1}: \mu_{1}>\mu_{2}
$$

Dengan:

H0 : Tidak berbeda nyata antara model PAKEM terhadap hasil belajar matematika peserta didik kelas VII MTs Negeri 2 Kendari

H1 : Ada perbedaan nyata antara model PAKEM terhadap hasil belajar matematika peserta didik kelas VII MTs Negeri 2 kendari

$\mu 1$ : Rata-rata hasil belajar matematika peserta didik yang diajar dengan model PAKEM.

$\mu 2$ : Rata-rata hasil belajar matematika peserta didik yang diajar dengan model pembelajaran langsung.

Rumus uji-t yang digunakan adalah sebagai berikut :

Berdasarkan perhitungan data hasil belajar matematika peserta didik (post-test), diperoleh data sebagai berikut :

$$
\begin{aligned}
& \bar{X}_{1}=67,7 \\
& \bar{X}_{2}=60,06 \\
& S_{1}{ }^{2}=135,0303 \\
& S_{2}{ }^{2}=145,0587 \\
& n_{1}=33 \\
& n_{2}=33
\end{aligned}
$$

Berdasarkan perhitungan di atas, diperoleh thitung $=2,561$, kemudian thitung dibandingkan dengan ttabeldengan taraf nyata $\alpha$ 0,05 dan $\mathrm{dk}=(33+33-2)=64$.

ttabel $\alpha==1,669$

Berdasarkan perhitungan di atas diperoleh nilai ttabel $=1,669$. Dengan demikian diperoleh nilai thitung $>$ ttabel atau 2,561 >1,669, sehingga $\mathrm{H} 0$ ditolak atau $\mathrm{H} 1$ diterima. Selain menggunakan uji-t, pengujian hipotesis dapat menggunakan SPSS. Hasil analisis uji hipotesis hasil belajar matematika peserta didik sebagai berikut:

Tabel 7

Hasil Uji Hipotesis

\begin{tabular}{cc}
\hline Statistik & Nilai Statistik \\
\hline $\mathrm{T}$ & 2,621 \\
\hline Sig.(2-tailed) & 0,011 \\
\hline
\end{tabular}

Berdasarkan Tabel 7 menunjukkan bahwa hasil belajar matematika peserta didikyang diajar dengan model PAKEM dan hasil belajar matematika peserta didik yang diajar dengan model pembelajaran langsung. Menggunakan aplikasi SPSS, diperoleh nilai sig. (2-tailed) adalah $\alpha$ (dengan $\alpha 0,05)$ maka H0 ditolak.

Berdasarkan hasil analisis baik menggunakan rumus uji-t maupun menggunakan aplikasi SPSS, menunjukkan bahwa $\mathrm{H}_{0}$ ditolak.

\section{Pembahasan}

Penelitian ini merupakan penelitian eksperimen tentang pengaruh model PAKEM terhadap hasil belajar peserta didik MTs Negeri 2 Kendari yang diajar dengan materi yang sama yaitu materi persamaan dan pertidaksamaan linear satu variabel. Model PAKEM yang dimaksud dalam penelitian ini adalah model pembelajaran yang mendorong peserta didik untuk mengetahui cara belajar dan bekerjasama dalam kelompok untuk mencari penyelesaian masalah-masalah di dunia nyata. Kelebihan dari metode pembelajaran ini yaitu peserta didik dituntut aktif dalam menjawab pertanyaanpertanyaan yang diajukan oleh guru sehingga dalam proses pembelajaran peserta didik lebih aktif. Metode pembelajaran ini juga sesuai dengan tuntutan Kurikulum 13 yang mengutamakan keaktifan peserta didik dalam proses pembelajaran. Penelitian ini terdapat dua kelas yaitu kelas $\mathrm{VII}_{5}$ sebagai eksperimen dan $\mathrm{VII}_{4}$ sebagai kelas control.

Waktu pelaksanaan pembelajaran dalam penelitian ini selama 20 jam pelajaran. Total pertemuan sebanyak 14 pertemuan, yaitu 6 kali pertemuan untuk pembelajaran di kelas eksperimen, 6 kali pertemuan untuk pembelajaran di kelas kontrol, 1 kali pertemuan untuk post test untuk kelas eksperimen dan 1 kali pertemuan post test untuk kelas kontrol. Post test diberikan waktu selama 60 menit. Sebelum diberikan post test, diberikan perlakuan berupa penerapan model PAKEMpada kelas eksperimen dan model pembelajaran langsung pada kelas kontrol, dengan materi yang sama yaitu materi persamaan dan pertidaksamaan linear satu variabel. 
Pada pertemuan pertama di awali dengan perkenalan diri, tujuan mengajar di kelas tersebut dan kegiatan pendahuluan yang berupa menyapa, mengecek kehadiran, membagi peserta didik dalam beberapa kelompok yang heterogen, membagikan bahan ajar, memberi motivasi, menyampaikan tujuan pembelajaran dan langkah-langkah pembelajaran. Kegiatan inti meliputi klarifikasi masalah, pengungkapan pendapat, evaluasi dan pemilihan, dan implementasi.

Dalam kegiatan klarifikasi masalah, disini peneliti memulai proses pembelajaran dengan pemberian beberapa pertanyaan kepada peserta didik. Kemudian peserta didik mengungkapkan pendapatnya atas jawaban dari pertanyaan tersebut. Peserta didik dari kelompok lain dapat memberikan jawaban lain atau masukan serta kritikan dari jawaban tersebut. Pertanyaan-pertanyaan yang telah disiapkan akan diajukan kepada peserta didik. Disinilah terjadi proses diskusi antara satu peserta didik dan peserta didik yang lain untuk menjawab pertanyaan yang diajukan oleh guru. Setelah pertanyaan telah dijawab maka guru menyimpulkan jawaban yang benar dari pertanyaan tersebut. Selanjutnya kegiatan evaluasi dan pemilihan. Disini guru membagikan LKPD kepada peserta didik. Kemudian peserta didik diminta untuk memperhatikan soal-soal dalam LKPD dan mendiskusikan jawaban-jawaban yang tepat dan menerapkan informasi-informasi yang didapat untuk menjawab soal. Selanjutnya peserta didik menuliskan jawaban-jawaban dari soal-soal tersebut. Kegiatan penutup adalah guru menyimpulkan hasil pembelajaran dan guru menutup pembelajaran dengan salam.

Berdasarkan hasil pengamatan, diperolehtingkat keterlaksanaan pembelajaran oleh guru pada pertemuan pertama dari seluruh aspek yang diamati adalah $78 \%$. Pada pertemuan pertama guru masih belum secara optimal menjalankan proses pembelajaran dengan model PAKEM karena peserta didik masih belum terbiasa dengan metode pembelajaran diskusi dan tanya jawab. Guru hanya sekedar memberikan beberapa pertanyaan yang kemudian apabila peserta didik masih keliru dalam menjawab pertanyaan tersebut guru langsung menjawab sendiri pertanyaan tersebut.

Pada pertemuan kedua tingkat keterlaksanaan oleh guru dari aspek yang diamati adalah $95 \%$. Pada pertemuan kedua guru sudah menjalankan proses pembelajaran menggunakan model PAKEM. Peserta didik diberikan kesempatan untuk mengemukakan pendapatnya atas suatu pertanyaan dan guru tidak langsung menyimpulkan jawaban yang tepat, tetapi menyimpulkan diakhir diskusi. Pada saat akhir pelajaran peserta didik akan memainkan games miskin yang berkaitan dengan materi yang dipelajari sehingga peserta didik aktif untuk bertanya jika belum paham, selain itu juga pada saat permainan berlangsung peserta didik dengan antusias mengikuti permainan sehingga peserta didik menjadi aktif.Pada pertemuan ketiga, keempat, kelima, dan keenam tingkat keterlaksanaan oleh guru dari aspek yang diamati mencapai $100 \%$. Keterlaksanaan pembelajaran terus meningkat dari pertemuan pertama sampai pertemuan akhir. Guru mampu menjalankan semua kegiatan pembelajaran dan peserta didik sudah lebih aktif dalam diskusi kelompok. Pada pertemuan keenam persentase keterlaksanaan pembelajaran oleh gurumencapai $100 \%$.Hal ini menunjukan bahwa keterlaksanaan pembelajaran oleh guru sudah sangat baik.

Aktivitas peserta didik selama proses pembelajaran merupakan salah satu indikator adanya keinginan peserta didik untuk belajar. Berdasarkan hasil pengamatan, diperoleh tingkat aktivitas peserta didik dalam proses pembelajaran pada pertemuan pertama dari seluruh aspek yang diamati yaitu $70 \%$. Pertemuan pertama peserta didik masih harus menyesuaikan diri dengan model PAKEM, peserta didik dituntut aktif dalam proses pembelajaran. Hanya beberapa peserta didik yang mau menjawab dan mengemukakan pendapatnya tentang soal-soal yang diberikan sedangkan beberapa peserta didik masih tidak ingin terlibat dalam kegiatan diskusi.

Pada pertemuan kedua peserta didik sudah mulai lebih aktif dalam menjawab soalsoal yang diberikan oleh guru. Peserta didik juga lebih aktif dalam menanggapi jawaban dari peserta didik yang lainnya, peserta didik juga lebih fokus dalam memperhatikan bahan ajar. Selain itu juga peserta didik aktif bertanya apabila ada hal-hal yang kurang jelas dalam LKPD. Tingkat aktifitas peserta didik dalam proses pembelajaran adalah $79 \%$.

Pada pertemun ketiga, keempat, kelima dan keenam tingkat akifitas peserta didik dalam proses pembelajaran meningkat yaitu $85 \%$, $89 \%$, 92\%, dan 93\%. Hal ini karena peserta 
didik sudah terbiasa dengan proses pembelajaran kelompok dan dengan metode tanya jawab dan diskusi. Peserta didik lebih aktif dalam menjawab pertanyaan oleh guru. Peserta didik juga lebih aktif dalam menanggapi jawaban dari peserta didik yang lain. Dalam pengerjaan soalsoal LKPD, peserta didik lebih fokus dalam mencari pemecahan soal-soal tesebut. Keterlaksanaan pembelajaran oleh peserta didik dari pertemuan awal sampai pertemuan akhir terus mengalami peningkatan. Pada pertemuan terakhir persentase keterlaksanaan pembelajaran mencapai 93\% hal ini menunjukan bahwa keterlaksaan pembelajaran oleh peserta didik sangat baik.

Berdasarkan uraian tingkat aktivitas peserta didik tersebut, dapat disimpulkan bahwa peserta didik memerlukan waktu untuk beradaptasi terhadap suatu pembelajaran yang mereka anggap baru, terutama dengan pembelajaran yang menuntut peserta didik aktif dalam pembelajaran sehingga diharapkan guru lebih sabar dan lebih menstimulus peserta didik agar mampu mengembangkan kemampuan mereka untuk mencari tahu pemecahan masalah yang dihadapi dan mampu mengemukakan pendapat mereka.

Data hasil belajar matematika peserta didik diperoleh dari nilai tes hasil belajar pada materi persamaan dan pertidaksamaan linear satu variabel. Tes tersebut diberikan kepada peserta didik setelah diberikan perlakuan berupa penerapan model PAKEM. Kelas ekperimen ini menggunakan model PAKEM.

Hasil post test yang diperoleh merupakan gambaran hasil belajar matematika peserta didik. Data tersebut kemudian diolah sehingga diperoleh nilai rata-rata hasil belajar matematika peserta didik pada kelas ekperimen. Hasil analisis data diperoleh nilai rata-rata hasil belajar peserta didik pada kelas eksperimen adalah $67,7 \%$. Berdasarkan kriteria pemahaman peserta didik terhadap suatu materi, nilai ratarata hasil belajar pada kelas eksperimen tergolong baik. Selain itu, berdasarkan nilai tes akhir peserta didik pada kelas eksprimen. Tingkat penguasaan materi peserta didik pada kelas eksperimen berdasarkan kategorinya, diperoleh sebanyak 6 peserta didik (18\%) pada kategori kurang, 6 peserta didik (18\%) pada kategori cukup, 16 peserta didik (49\%) pada kategori baik dan 5 peserta didik (15\%) pada kategori sangat baik.
Data hasil belajar matematika peserta didik diperoleh dari nilai tes hasil belajar pada materi persamaan dan pertidaksamaan linear satu variabel. Tes tersebut diberikan kepada peserta didik setelah diberikan perlakuan berupa penerapan model pembelajaran langsung.

Hasil post test yang diperoleh merupakan gambaran hasil belajar matematika peserta didik. Data tersebut kemudian diolah sehingga diperoleh nilai rata-rata hasil belajar matematika peserta didik pada kelas kontrol. Hasil analisis data diperoleh nilai rata- rata hasil belajar peserta didik pada kelas kontrol adalah $60,06 \%$. Berdasarkan kriteria pemahaman peserta didik terhadap suatu materi, nilai ratarata hasil belajar pada kelas kontrol tergolong cukup. Selain itu, berdasarkan nilai tes akhir peserta didik pada kelas kontrol. Tingkat penguasaan materi peserta didik pada kelas kontrol berdasarkan kategorinya, diperoleh sebanyak 2 peserta didik (7\%) pada kategori gagal, 10 peserta didik (30\%) pada kategori kurang, 9 peserta didik (27\%) pada kategori cukup, dan 12 peserta didik (37\%) pada kategori baik.

Berdasarkan hasil analisis hasil belajar matematika peserta didik yang diajar dengan menggunakan model PAKEMdan model pembelajaran langsung dapat disimpulkan bahwa penguasaan peserta didik pada materi persamaan dan pertidaksamaan linear satu variabel pada kelas eksperimen sudah baik, sedangkan pada kelas kontrol masih tergolong cukup.

Pada kelas eksperimen terdapat 5 peserta didik yang pemahamannya tergolong sangat baik berbeda dengan kelas kontrol yang tidak terdapat peserta didik yang tingkat kemampuannya sangat baik. Selain itu juga pada kelas kontrol terdapat 2 peserta didik yang termasuk dalam kategori gagal dalam pemahamannya dalam penguasaan suatu materi.

Perbedaan hasil belajar matematika peserta didik yang pembelajarannya menggunakan model PAKEM dengan pembelajaran menggunakan model pembelajaran langsung dapat diperoleh dengan melakukan uji hipotesis rata-rata hasil belajar matematika peserta didik pada kelas eksperimen dan kelas kontrol dengan menggunakan statistik uji t sampel independen. Namun, sebelum melakukan hal itu terlebih dahulu dilakukan uji normalitas data kelas eksperimen dan kelas 
kontrol dan uji homogenitas varians data kedua kelompok sampel.

Berdasarkan uji normalitas dengan menggunakan statistik Chi-kuadrat, data hasil belajar matematika peserta didik kelas eksperimen dan kelas kontrol berdistribusi normal. Selanjutnya, berdasarkan hasil uji homogenitas varians hasil belajar matematika peserta didik kelas eksperimen dan kelas kontrol dengan menggunakan uji-F, menunjukkan bahwa data hasil belajar matematika peserta didik kedua kelompok memiliki varians yang homogen.

Tahap terakhir adalah dilakukan uji-t untuk menjawab hipotesis penelitian. Kriteria pengujian hipotesis adalah terima $\mathrm{H}_{0}$ jika $\mathrm{t}<\mathrm{t}_{(\boldsymbol{\alpha}} \alpha$ ); dk), dimana $\mathrm{t}_{(\mathrm{\alpha}, \mathrm{d}}$ diperoleh dari daftar distribusi $\mathrm{t}$ dengan $\mathrm{dk}=\left(\mathrm{n}_{1}+\mathrm{n}_{2}-2\right)$, dengan $\mathrm{dk}=64$ dan $\alpha$ $=0,05$. Berdasarkan perhitungan, dengan $\alpha=$ 0,05 diperoleh nilai $t_{\text {hitung }}=2,561$ dan nilai $t_{\text {tabel }}$ $=1,669$. Dengan demikian diperoleh nilai $t_{\text {hitung }}>t_{\text {tabel }}$ atau 2,561>1,669, maka kriteria pengujian hipotesis adalah tolak $\mathrm{H}_{0}$ atau terima $\mathrm{H}_{1}$.

Berdasarkan perhitungan di atas, dapat diketahui bahwa ada perbedaan nyata antara model PAKEM dengan model pembelajaran langsung terhadap hasil belajar matematika peserta didik kelas VII MTs Negeri 2 Kendari. Hal ini ditunjukkan dengan rata-rata hasil belajar peserta didik yang diajar dengan model PAKEM (kelas eksperimen) lebih tinggi daripada rata-rata hasil belajar peserta didik yang diajar dengan model pembelajaran langsung (kelas kontrol). Sehingga dapat simpukan bahwa terdapat pengaruh model PAKEM terhadap hasil belajar matematika peserta didik kelas VII MTs Negeri 2 Kendari.

\section{Simpulan dan Saran}

\section{Simpulan}

Berdasarkan hasil penelitian dan pembahasan dalam penelitian ini, maka dapat dikemukakan beberapa kesimpulan sebagai berikut:

1. Hasil belajar matematika peserta didik kelas VII MTs Negeri 2 Kendari yang pembelajarannya menggunakan model PAKEM memiliki nilai rata-rata sebesar 67,7, median sebesar 71, modus sebesar 81, standar deviasi sebesar 11,620, varians sebesar 135,030, nilai maksimum sebesar 82 , nilai minimum sebesar 42 , skewness 0,794 , dan kurtosis sebesar $-0,259$. Tingkat penguasaan materi peserta didik pada kelas eksperimen berdasarkan kategorinya, diperoleh sebanyak 6 peserta didik $(18 \%)$ pada kategori kurang, 6 peserta didik (18\%) pada kategori cukup, 16 peserta didik (49\%) pada kategori baik dan 5 peserta didik (15\%) pada kategori sangat baik.

2. Hasil belajar matematika peserta didik kelas VII MTs Negeri 2 Kendari yang pembelajarannya menggunakan model pembelajaran langsung memiliki nilai ratarata sebesar 60,06, median sebesar 58, modus sebesar 58, standar deviasi sebesar 12,044 , varians sebesar 145,059 , nilai maksimum sebesar 79 , nilai minimum sebesar 35, skewness $-0,226$, dan kurtosis sebesar $-0,559$. Tingkat penguasaan materi peserta didik pada kelas kontrol berdasarkan kategorinya, diperoleh sebanyak 2 peserta didik (6\%) pada kategori gagal, 10 peserta didik $(30 \%)$ pada kategori kurang, 9peserta didik $(27 \%)$ pada kategori cukup, dan 12 peserta didik (37\%) pada kategori baik.

3. Model PAKEM mempunyai pengaruh terhadap hasil belajar matematika peserta didik kelas VII MTs Negeri 2 Kendari.

\section{Saran}

Berdasarkan hasil penelitian ini, peneliti memberikan saran kepada:

1. Guru dapat memilih metode pembelajaranyang sesuai dengan kondisi kelas dan tuntutan peserta didik agar tujuan pembelajaran dapat tercapai salah satu contoh model pembelajaran yang dapat digunakan adalah model PAKEM dimana metode ini dapat menjawab tuntutan Kurikulum 13 yang mengutamakan keaktifan peserta didik, dan diharapkan guru berusaha untukmengeksplorasi pengetahuan peserta didik seperti menggunakan LKPD dan media pembelajaran untuk menunjang proses pembelajaran yang lebih aktif, efektif dan efisien.

2. Peserta didik diharapkan untuk selalu aktif dan terlibat langsung dalam pembelajaran agar dapat memahami materi pembelajaran dengan baik, melaksanakan tugas kelompok 
sesuai dengan tanggung jawabnya terhadap diri sendiri dan kelompoknya. .

\section{Daftar pustaka}

Aiken, L. R. (1985). Three Coefficients For Analyzing The Reliability, and Vanlidity of Ratings. Educational And Psychological Measurement. 45(3): 131-142.

Eka Lestari, K, \& Mokhammad, RY. (2015). Peneltian Pendidikan Matematika. Bandung: Refika Aditama.

Lestari, KE., \& Yudhanegara, RM. (2015). Penelitian Pendidikan Matematika. Bandung: Refika Aditama.

Mulyasa, E. (2006). Praktik Penelitian Tindakan Kelas. Bandung: Rosda Karya.

Pitalis, MB. (2015). Penerapan Model Pembelajaran Aktif Kreatif Dan Menyenangkan (Paikem) Terhadap Hasil Belajar Mahasiswa Pendidikan Geografi IKIP PGRI Pontianak. Sosial Horizon: Jurnal Pendidikan Sosial. 2(1): 40-55.
Rahmawati., As Mestawaty, A., \& Lilies. Penerapan Model Pembelajaran Paikem Untuk Meningkatkan Hasil Belajar IPA Di Kelas V SDN 3 Tompoh. Jurnal Kreatif Tadulako Online. 5 (10): 230-259.

Rosdiana, \& Anwar, A. (2014). Perbedaan Hasil Belajar Matematika Sekolah Menengah Atas Ditinjau Dari Model Pembelajaran Kooperatif Dan Kemampuan Bahasa Inggris. Jurnal Pendidikan Matematika. 5(2): 150160.

Rusman. (2010). Model-Model Pembelajaran (Mengembangkan Profesionalisme Guru Edisi Kedua). Jakarta: Raja Grafindo Persada Mulyasa.

(2014). Model-Model Pembelajaran. Jakarta: Rajawali Pers.

Sugiyono. (2011). Metode Penelitian Pendidikan. Bandung: Alfabeta.

Zarkasyi, W. (2015). Penelitian Pendidikan Matematika. Bandung: Refika Aditama. 